\title{
THE INFLUENCE OF STOCK CHARACTERISTICS ON RETURN IN CONSUMER GOODS INDUSTRY COMPANIES
}

\author{
Ivan Alexander Nanlohy \\ Faculty of Business and Economics, Universitas Surabaya \\ Putu Anom Mahadwartha \\ Faculty of Business and Economics, Universitas Surabaya \\ anom@staff.ubaya.ac.id \\ Arif Herlambang \\ Faculty of Business and Economics, Universitas Surabaya \\ arif_herlambang@staff.ubaya.ac.id
}

\begin{abstract}
This study aims to determine the influence of stock characteristics with stock returns on consumer goods industry companies listed on the Indonesian Stock Exchange period 2011 2015. Stock characteristics are illiquidity, size, beta, risk and dividend yield. This study uses quantitative approach by using multiple linear regression method in the form of panel data. This study uses a sample of consumer goods industry companies listed on the Indonesia Stock Exchange period 2011-2015. The number of samples used in this study is 125 years of observation consisting of 25 companies. The finding of this study indicates that the influence of stock characteristics with stock returns. Illiquidity has no significant positive effect on stock return. Size has no significant positive effect on stock return. Beta has a significant positive effect on stock return. Risk has a significant negative effect on stock return. Dividend yield has a significant negative effect on stock return.
\end{abstract}

Keywords: stock characteristics, stock return, illiquidity

\begin{abstract}
Abstrak
Penelitian ini bertujuan untuk mengetahui adanya pengaruh karakteristik saham dengan return saham pada perusahaan industri barang konsumsi yang tercatat di Bursa Efek Indonesia periode 2011-2015. Karakteristik saham yaitu illiquidity, size, beta, risk dan dividend yield. Penelitian ini menggunakan pendekatan kuantitatif dengan menggunakan metode regresi linear berganda dalam bentuk data panel. Penelitian ini menggunakan sampel berupa perusahaan industri barang konsumsi yang tercatat di Bursa Efek Indonesia periode 2011-2015. Jumlah sampel yang digunakan dalam penelitian ini adalah sebesar 125 tahun observasi yang terdiri dari 25 perusahaan. Temuan penelitian ini menunjukan bahwa adanya pengaruh karakteristik saham dengan return saham. Illiquidity berpengaruh positif tidak signifikan terhadap return saham. Size berpengaruh positif tidak signifikan terhadap return saham. Beta berpengaruh positif signifikan terhadap return saham. Risk berpengaruh negatif signifikan terhadap return saham. Dividend yield berpengaruh negatif signifikan terhadap return saham.
\end{abstract}

Kata Kunci: stock characteristics, stock return, illiquidity

JEL: G10 


\section{Research Background}

The financial decision for both individuals and companies always considers risk and return. Those two aspects cannot be separated, because it is connected each other. The company which is go public will surely give information related to the liquidity of the company's assets. The liquid assets are easy to be sold in investors market and speculators are interested to buy. The obstacles from the company itself is when it has the liquid assets, it would be difficult for the company to sell them for investors and speculators. It would be difficult for them to use it to obtain benefits.

Amihud and Mendelson (1991) stated that liquidity is the important factor in determining the asset pricing. The lower the liquidity assets (the higher the trading cost), the higher the expected return. It doesn't mean holding liquid asset would be beneficial because of the big amount of transaction cost, it consumes the profit. In designing a portfolio, a manager needs to consider the reluctance of client risk and the future of investment. Investors with the long holding time would get benefits from having liquid assets. Therefore, financial analysts also need to consider the changing of assets liquidity on asset value.

Amihud dan Mendelson (1989) did research on the influence of beta, size, residual risk and illiquidity on stock return; data used is the data from NYSE stock exchange (New York Stock Exchange) in the period of 1960 - 1979. Variables in this research are independent (beta, risk, size and illiquidity) and dependent variables (stock return). Amihud dan Mendelson (1989) found that illiquidity and beta have positive impacts on stock return; while size and risk have negative impacts on stock return.

Amihud (2002) did research to explain the relationship of illiquidity impacts on stock return. The samples of the research use data from New York Stock Exchange (NYSE) in the period of $1964-1997$. The data is from daily and monthly shares trading in database center for research of securities prices of the University of Chicago (CSRP). Variables in this research are dependent (stock return) and independent variables (illiquidity, size, risk, dividend yield and beta). Amihud (2002) found that illiquidity and beta have positive impacts on stock return, while size, risk and dividend yield have negative impacts.

Cao and Petrasek (2014) undertook research about the impacts of illiquidity on stock return in the period of financial crisis. The data is from the American companies' shares registered in NYSE, AMEX and NASDAQ in the period of 1993 - 2011. This research focused on 48 days ( $1 \%$ of the samples) and 24 days $(0.5 \%$ of the samples) with the biggest shock is detrimental to the market liquidity in the period of 1993 and 2011. The variables in this research consist of dependent (stock return) and independent variables (market beta, liquidity beta, PIN, illiquidity, investment company ownership, bank ownership, other ownership, ownership concetration, bid ask spread, momentum, standard deviation, leverage, book to market capitalization, market capitalization). Cao dan Petrasek (2014) found that beta, size and risk have negative impacts on stock return; while illiquidity doesn't have any impacts on stock return.

Amihud et al. (2015) did research on illiquidity premium in stock markets which consists of 45 countries. Those countries consist of 19 emerging markets and 26 developed markets in the period of 1990 - 2011. The variables in this research consist of dependent (stock return) and independent variables (illiquidity, risk and size). Amihud et al. (2015) found that illiquidity has positive impacts on stock return, while risk and size have negative impacts on stock return. 
Lemmon and Nguyen (2015) did research on the relationship of dividend yield and stock return. The samples of this research are all shares registered in Hongkong stock exchange, taken from datastream in the period of 1981 - 2010. Variabels in this research consist of dependent variable (stock return) and independent variables (size and dividend yield). Lemmon dan Nguyen (2015) found that dividend yield has positive impact on stock return, while size has negative impact on stock return.

Meanwhile, Patel (2012) did research to compare the performance of small companies by using the return of the companies in developed stock markets and emerging stock markets. The period of research is July 1996 - December 2010. The number of observation in this research is 173 . The comparison used size premium (small firm return minus large firm return). The dependent variable in this research is return and independent variable is size. Patel (2012), found size premium (small firm return minus large firm return) inconsistent, both in developed stock markets and emerging stock markets.

Chelley-Steeley et al. (2015) conducted a study on the effect of non trading in the illiquidity ratio. Non trading is a day when securities are not traded. The sample of this study is common stocks listed on the NYSE, AMEX and NASDAQ. The period of research is in January 1960-December 2008. This study used an analysis simulation on the illiquidity ratio. Chelley-Steeley et al. (2015) found that the effects of non-trading make the illiquidity ratio become bias.

From the results of the description above, as well as the research gap, the research variables chosen include illiquidity, size, risk, beta and dividend yield.

Amihud and Mendelson (1989), Amihud (2002) and Amihud et al. (2015) found that illiquidity has a positive impact on stock returns. Amihud and Mendelson (1989) stated that illiquidity is measured by using bid-ask spread. Amihud and Mendelson (1986) in Amihud and Mendelson (1989) stated that investors who rationally choose assets to maximize expected returns exceed trading costs or equilibrium, higher spread assets are allocated to investors with longer holding periods. This proves that illiquidity can increase stock returns. However, Cao and Petrasek (2014) found that illiquidity had no effect on stock returns during the financial crisis and Chelley-Steeley et al. (2015) found the non-trading effect on the illiquidity ratio.

Amihud and Mendelson (1989), Amihud (2002), Cao and Petrasek (2014), Lemmon and Nguyen (2015) and Amihud et al. (2015) found that size has a negative impacts on stock returns. Brown et al. (1983) in Amihud (2002) found that both the expected and the unexpected impacts of illiquidity markets are stronger for small companies than large companies. This shows that size and stock return are inversely affected. However, Patel (2012) found that the size effect is not consistent from year to year.

Amihud and Mendelson (1989), Amihud (2002) found that beta has a positive impacts on stock returns. This shows that the high beta can increase stock returns. However, Cao and Petrasek (2014) found that beta has negative impacts on stock returns.

Amihud and Mendelson (1989), Amihud (2002) and Amihud et al. (2015) found that risk has negative impacts on stock returns. Constantinides and Scholes (1980) in Amihud (1989) stated that a higher residual risk is related to a lower expected return. Furthermore, Cao and Petrasek (2014) found that risk has negative impacts on stock returns during the financial crisis. This shows that the relationship is inversely proportional between risk and stock return.

Amihud (2002) found that dividend yield has negative impacts on stock returns. Redding (1997) in Amihud (2002) stated that large investors prefer companies with high liquidity and also prefer to receive dividends. Whereas, Lemmon and Nguyen (2015) found that dividend yield has positive impacts on stock returns.

This research will be conducted in one of the industrial business entities that have gone public on the Indonesian stock exchange during 2011-2015. Business entities listed on the IDX are divided into 9 corporate sectors, namely; agriculture, mining, basic industry and chemicals, miscellaneous industry, consumer goods industry, property, real estate and building 
construction, infrastructure, utilities and transportation, finance, trade, service and investment .

The selection of industrial sectors to be used as research samples is based on market capitalization, risk, return and earnings per share. In terms of selection of the industrial sector, it begins with choosing a high return. The investors tend to emphasize the amount of return. The greater the return is followed by the amount of risk in investment. Therefore, the industrial sectors which have high risk and high return are chosen as the industry sector for the study. To compare one sector with another, the index data of each sector is used in the IDX, which is from finance.yahoo.com in 2015. This is also supported by the large market capitalization and earnings per share. Market capitalization reflects the value of a company in the market. Earnings per share reflect the income of each share that the shareholders will get. The higher the value of earnings per share, the better it would be.

\subsection{The influence of Illiquidity on Stock return}

Amihud and Mendelson (1986) in Amihud and Mendelson (1989) stated that investors who rationally choose assets to maximize expected returns to be higher than trading costs or equilibrium, higher spread assets; are those the ones in longer holding periods. Expected returns are increasing in accordance with the presentation of bid ask spread. Pastor and Stambaugh (2003) stated that stocks with a greater risk of illiquidity must get a higher illiquidity risk premium. Atkins and Dyl (1997) in Amihud (2002) found a strong positive relationship between stocks with bid-ask spread and reciprocal of turnover ratio that measures the holding period. Amihud (2002) stated that expected market illiquidity positively affects the expected stock excess return (stock return exceeds the treasury bill rate). This is consistent with the positive cross sectional relationship between stock returns and illiquidity. If investors anticipate high market liquidity, they will reduce stock prices to produce higher expected returns. This shows stocks excess return, which is traditionally interpreted as a risk premium including a premium for illiquidity. Stocks are not only risky, but are less liquid than shortterm treasury securities. First, bid ask spreads and brokerage fees are greater for shares than for treasury securities. That means the cost of illiquidity is greater for shares. Second, the size of transactions in the treasury securities is greater; investors can exchange the bills and records in very large amounts (tens of millions of dollars) without being affected by the prices. However, block transactions in stocks, with the high cost of illiquidity, affect the price. Based on the reason that the expected yields of shares exceeding the treasury securities, it is considered as compensation for illiquidity, in addition to the standard interpretation as compensation for risk.

$\mathrm{H}_{1}=$ illiquidity positively affect stock return

\subsection{The influence of Size on Stock Return}

Brown et al. (1983) in Amihud (2002) found that the impacts of the expected and unexpected illiquidity market are stronger on small than large companies. Berk (1995) in Amihud (2002) stated that size is inversely proportional to expected return. Amihud (2002) stated that the existence of small firm effect, namely small companies, can produce a greater return than larger companies. In small companies, the condition tends to change responding to the impacts of the business environment, so that it is more volatile for stock movements compared to large companies; that tend to be more stable in movement of their shares, because they are not affected by the impacts of the business environment. Anomalies that occur make small companies produce abnormal returns, so when it is compared, the return of small companies is greater than large companies. It is because companies with larger sizes should be able to generate greater returns than small companies.

$\mathrm{H}_{2}=$ Size negatively affect stock return 


\subsection{The influence of Beta on Stock Return}

Black et al. (1972) found that returns are positively related to beta. This can be seen from the results of this study; cross sectional regression mean excess returns on the portfolio against beta estimation indicate a positive linear relationship between beta and return. Muhardi and Irawan (2012) stated that market risk is measured by beta; the amount of beta numbers shows a large change in stocks return in the market. Beta is used to measure systematic risk. Systematic risk is uncertainty that is inherent in the market that cannot be avoided by diversifying. Therefore, the size of the return is influenced by systematic risks that occur in the market. $\mathrm{H}_{3}=$ beta positively affect stock return

\subsection{The influence of Risk on Stock Return}

Constantinides and Scholes (1980) stated that taxes on capital gains make investors suffer losses due to having to pay the tax. To avoid paying taxes on capital gains, hedging is done by using a call option. By doing hedging, it makes the long and short-term marginal tax rate of capital gains and losses to zero. Therefore, the increasing of the call option value also increases residual risk. The call option is inversely proportional to stock returns. Limitations in investors form a portfolio, resulting in diversification does not eliminate residual risk. This makes the amount of residual risk affect the call option value but decreases the expected return. Therefore, it can be concluded that the higher residual risk is associated with a lower expected return.

$\mathrm{H}_{4}=$ risk negatively affect stock return.

\subsection{The influence of Dividend Yield on Stock Return}

Redding (1997) in Amihud (2002) stated that large investors prefer companies with high liquidity and also prefer to receive dividends. Large investors in this study are institutional investors who have large companies and the management of these companies is tasked with minimizing the cost of equity or fulfilling fiduciary responsibilities.

Fiduciary is someone who is ethically and legally responsible for managing one's and group's assets. So, they should be careful in managing assets. Fiduciary is responsible for the general welfare of the owner of the assets managed. The high dividend yield is considered by investors to guarantee large liquidity (ignoring the tax consequences). This is in line with the bird in hand theory in Gitman and Zutter (2012). Investors prefer to get dividends at this time compared to obtaining capital gains that are considered uncertain. Therefore, there is a factor of uncertainty and fiduciary responsibilities which make large investors tend to choose to get dividends

$\mathrm{H}_{5}=$ Dividend yield positively affect stock return .

Based on the description above, it can be described the conceptual research model shown in Figure 1. 


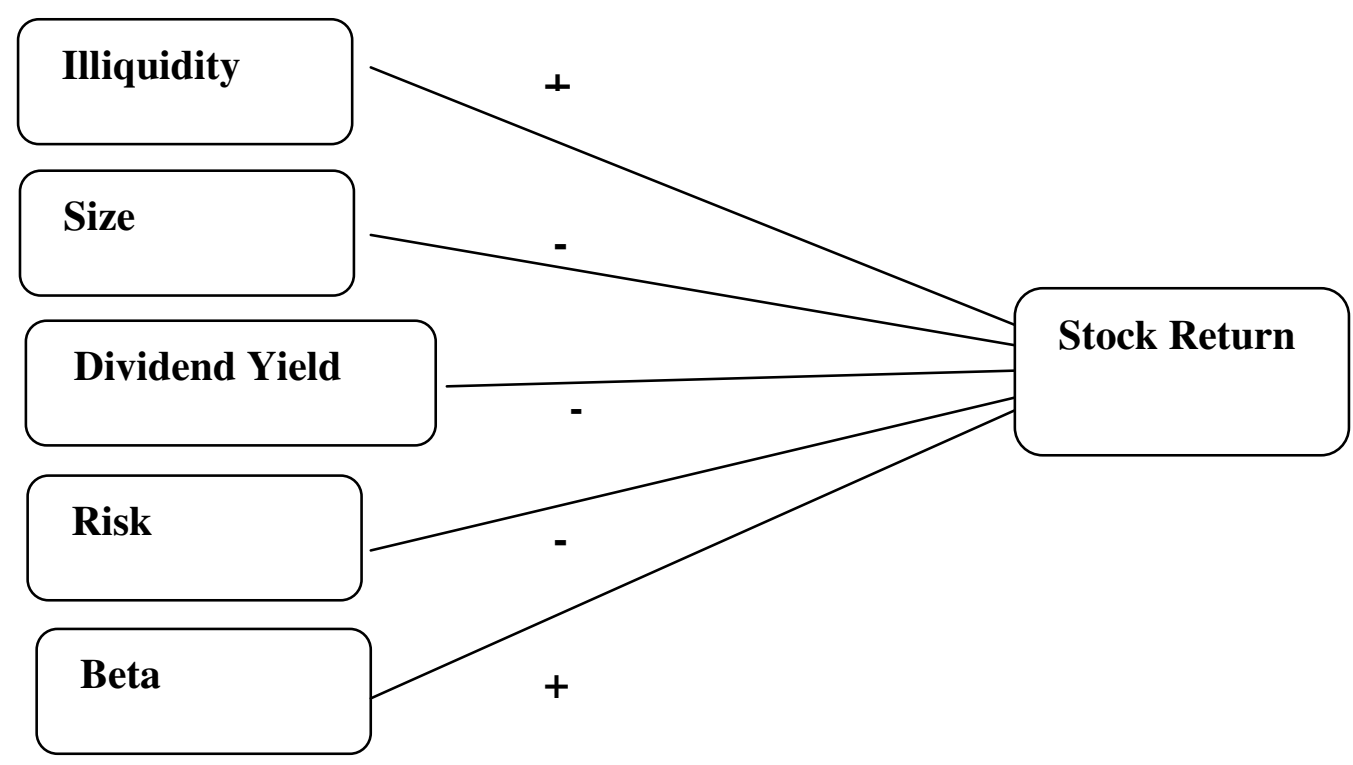

Figure 1. The influence of independent variables on dependent variables

\section{Research Method}

This research is included in the type of basic research, namely research to discuss problems in general and developments from the previous research. This study is based on objectives included in causal research because this study aims to explain the effect of illiquidity, size, beta, risk, and dividend yield on stock returns in Indonesia. The approach of this study is a quantitative approach because this study uses quantitative data to prove the validity of the results of the study.

Based on the analysis, the variables used in this study can be divided into 5 independent variables and 1 dependent variable. The independent variables in this study are illiquidity, size, beta, risk, and dividend yield. Meanwhile, the dependent variable in this study is the stock return.

This study uses secondary data, namely stock price data, stock volume, dividends and the number of shares outstanding will be processed in order to obtain illiquidity, size, beta, risk, and dividend yield to explain the effect on the stock return. Stock price and volume data are obtained from the website www.finance.yahoo.com and www.idx.co.id. Data on the number of outstanding shares and dividends obtained from annual reports that can be downloaded on each company website or through www.idx.co.id. The time period used is 01/01/2011 until $12 / 31 / 2015$.

The measurement level used in the study is the ratio. Ratio is a unit that reflects the actual value of an object to be examined in full compared to other scales and to obtain its value by operating mathematically.

The population in this study is companies in consumer goods industry listed in Stock Exchange in 2011-2015. The research sample was 25 companies in consumer goods industry listed in the IDX in the period of 2011-2015 that met the requirements. The requirement in sample selection include: Not from the financial and banking sectors, having audited financial statements for the period of 2011-2015, share price data from selected industrial companies during the period of 2011-2015. In determining the sample and population, one of the industries on the IDX was chosen by comparing risk, return, market capitalization and EPS. After selecting one of the industries listed on the IDX, checking the completeness of stock price data and financial statements for the period of 2011-2015 is conducted. Companies in selected industries without complete data will not be used as samples.

This study uses multiple linear regression analysis as an analysis method. This analysis 
is conducted to determine the relationship between the independent variables and the dependent variable whether each independent variable is positively or negatively related and to predict the value of the dependent variable if the value of the independent variable increases or decreases. With the help of the application Eviews 8 regression analysis was carried out. Multiple linear regression models can be expressed in the equation as follows:

$$
\begin{array}{ll}
Y=\alpha+\beta_{1} I L L & +\beta_{2} \text { Size }+\beta_{3} \text { Beta }_{3}+\beta_{4} \text { Risk }+\beta_{5} D Y+e \\
\ldots \ldots \ldots \ldots \ldots \ldots \ldots \ldots \ldots \ldots \ldots \ldots \ldots \ldots . .(1) \\
\text { Information: } & \\
\text { Y } & =\text { stocks return } \\
\alpha & =\text { constants } \\
\text { ILL } & =\text { Illiquidity } \\
\text { Size } & =\text { Size } \\
\text { Beta } & =\text { Beta } \\
\text { Risk } & =\text { Risk } \\
\text { DY } & =\text { Dividend Yield } \\
\text { e } & =\text { Error Term } \\
\beta_{1}, \beta_{2}, \beta_{3}, \beta_{4}, \beta_{5} & =\text { Regression coefficients for each independent variable }
\end{array}
$$

\section{Result and Discussion}

Descriptive statistics inform the number of observations, mean, median, standard deviation, maximum and minimum of all variables in the study. The data used are companies registered with the consumer goods industry during 2011-2015 and meet the research criteria. Processing data uses Eviews 8. The following results are in the form of descriptive statistics table 3.1.

Table 1. Descriptive Statistic

\begin{tabular}{lrrrrrr}
\hline & & & & & DIVIDEND \\
& RETURN & ILLIQ & SIZE & BETA & RISK & YIELD \\
\hline Mean & 0.000029 & 0.0000015 & 29.16283 & 0.635633 & 0.029106 & 0.013556 \\
Median & 0.000197 & -0.0000000001 & 29.00465 & 0.638342 & 0.023603 & 0.008846 \\
Maximum & 0.004529 & 0.000060 & 33.71183 & 1.615073 & 0.240389 & 0.086207 \\
Minimum & -0.016542 & -0.000021 & 24.62887 & -1.46856 & 0.003442 & 0 \\
Std. Dev. & 0.002458 & 0.0000072 & 2.434221 & 0.46619 & 0.027551 & 0.0156 \\
Skewness & -3.560992 & 5.358868 & -0.00582 & -0.52003 & 5.384854 & 1.42638 \\
Kurtosis & 22.76074 & 41.74539 & 2.091824 & 5.000772 & 37.39125 & 5.919206 \\
Observations & 125 & 125 & 125 & 125 & 125 & 125 \\
\hline
\end{tabular}

Source: Eviews 8, processed

Table 1 presents the results of each variable: return, illiquidity, size, beta, risk and dividend yield. From the table above, the information on the number of observations of this study is 125 . The maximum value between the variables is in the size variable that is equal to 33.71183. Meanwhile, the minimum value between these variables is in the beta variable which is equal to -1.46856 . The highest mean value among the 6 variables is in the size variable that is equal to 29.16283 and the lowest mean value is in the variable iliuidity that is equal to 0.0000015 . The highest median value is in the size variable that is equal to 29.00465 while for the lowest mean value there is the variable liquidity of -0.0000000001 . The largest standard deviation value is in the size variable that is equal to 2.434221 and the lowest on the liquidity variable that is equal to 0.0000072 . 
The results of regression testing is :

Table 2. Regression Test Result

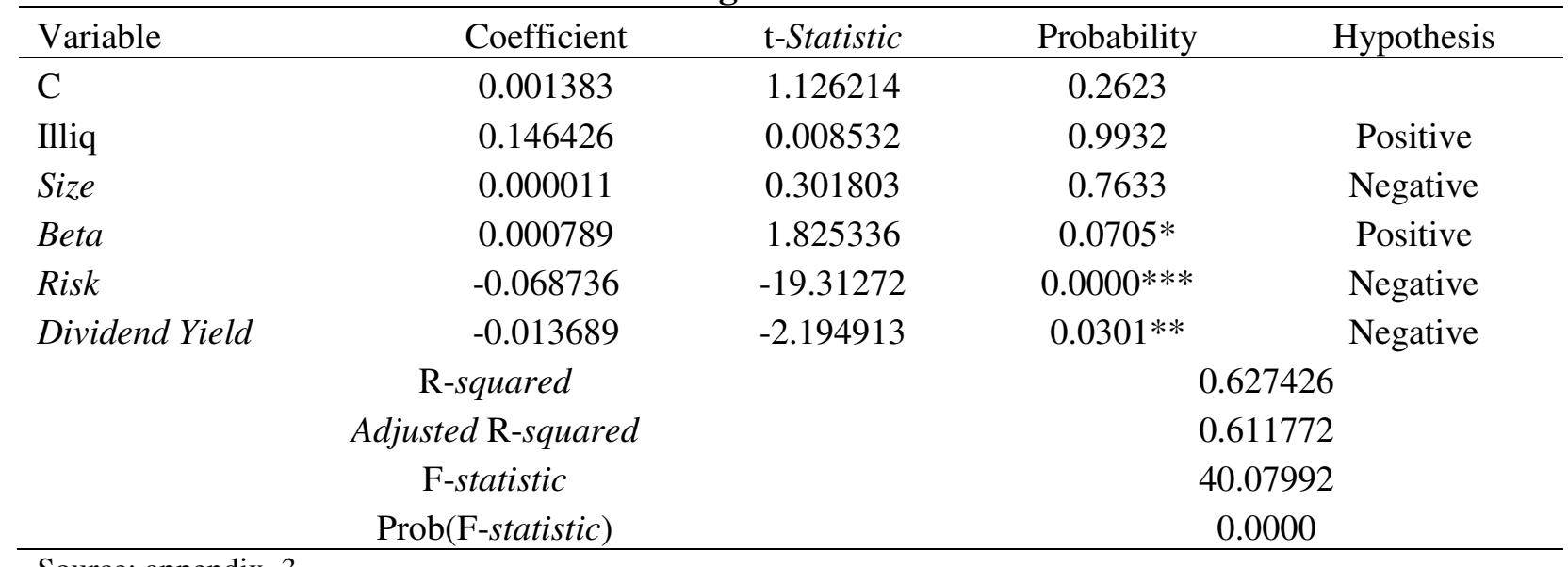

Source: appendix 3

Information:

Illiq : illiquidity

$$
\begin{array}{r}
* \text { : significant on } 10 \% \\
* * \text { : significant on } 5 \% \\
* * * \text { : significant on } 1 \%
\end{array}
$$

The multiple linear regression equations for this study are:

$$
\begin{aligned}
\text { stock return }= & 0.001383+0.146426 .11 \text { liq }+0.000011 . \text { size }+0.000789 . \text { beta }- \\
& 0.068736 . \text { risk }-0.013689 . \text { dividend yield } .
\end{aligned}
$$

The multiple linear regression equation above shows the stock return as the dependent variable and illiquidity, size, beta, risk, and dividend yield as independent variables

Table 3.2 shows that the illiquidity coefficient is 0.146426 with a significance level of 0.9932 means that the illiquidity variable has a positive but not significant effect on the stock return of consumer goods industry companies listed in the IDX of 2011-2015.

Chelley-Steeley et al. (2015) stated that illiquidity ratio is a measurement of bias when the measurement period includes days where securities are not traded (non trading). Measurement problems arise because of zero volume. Mathematical software used to calculate liquidity ratios and it cannot be divided by zero. The result of eliminating zero volume has an impact on the absolute nature of return which serves to reduce the illiquidity ratio, while zero volume elimination increases the illiquidity ratio. The overall effect increases the bias in the ratio. Therefore, illiquidity is not significant to stock return.

Cao and Petrasek (2014) found that illiquidity was not significant for stock returns during financial crisis. The financial crisis that occurred during 1993-2011 period consisted of: the economic crisis in Asia (27 October 1997), the LCTM crisis and Russia's political uncertainty (31 September 1998), terrorist attacks on the US (17 September 2001), before the collapse of Bear Sterns (10 March 2008) and when lawmakers reject the bailout for US Financial Industry (29 September 2008). This financial crisis affects the relationship between illiquidity and stock returns to be insignificant.

Table 2 shows that the size coefficient is 0.000011 with a significance level of 0.7633 means that the size variable has a positive but not significant impact on stock return of consumer goods industry companies listed in IDX 2011-2015.

Patel (2012) stated that neither size effect nor reverse size effect are no longer in developed stock markets and emerging stock markets. This research was carried out during the period of 1996-2010 by comparing small companies with large companies in developed stock markets and emerging stock markets using size premium (small firm return minus large firm returns). In developed stock markets, size premiums are positive for 10 years and 4 years are 
negative. Meanwhile, for emerging stock markets, size premiums are negative for 5 years and positive for 9 years. This makes size premium inconsistent.

Table 2 shows that beta coefficient is 0,000789 with significance level of 0.0705 means that beta variable has positive and significant impacts on the stock return of consumer goods industry companies listed in the IDX 2011-2015.

Black et al. (1972) found that returns positively related to beta. This can be seen from the results of this study, cross sectional regression mean excess returns on the portfolio against beta estimation; which show positive linear relationship between beta and return. Muhardi and Irawan (2012) stated that market risk is measured by beta, the amount of beta numbers shows a large change return of stocks to the market. Beta is used to measure systematic risk. Systematic risk is uncertainty that is inherent in the market that cannot be avoided by diversifying. Therefore, the size of the return is influenced by systematic risks that occur in the market.

Table 2 shows that the risk coefficient is -0.068736 with significance level of 0.0000 , meaning the risk variable has negative and significant impacts on the stock return of consumer goods industry companies listed in the IDX 2011-2015.

Constantinides and Scholes (1980) stated that taxes on capital gains make investors suffer losses due to having to pay the tax. To avoid paying taxes on capital gains, hedging is done by using a call option. By doing hedging makes the long and short-term marginal tax rate of capital gains and losses to zero. Therefore, increasing the call option value also increases residual risk. However, the call option is inversely proportional to stock returns. Limitations in investors form a portfolio resulting in diversification carried out do not eliminate residual risk. This makes the amount of residual risk affect the call option value but decreases the expected return. Therefore, it can be concluded that the higher residual risk is associated with a lower expected return.

Table 2 shows that the dividend yield coefficient is -0.013689 with significance level of 0.0301 , meaning the dividend yield variable has negative and significant impacts on stock return of the consumer goods industry companies listed in the IDX 2011-2015.

Redding (1997) in Amihud (2002) stated that large investors prefer companies with high liquidity and also prefer to receive dividends. Large investors in this study are institutional investors who have large companies and the management of this company is tasked with minimizing the cost of equity or fulfilling fiduciary responsibilities. Fiduciary is someone who is ethically and legally responsible for managing one's and group's assets. So that it is very careful in managing assets. Fiduciary is responsible for the general welfare of the owner of the assets managed. The high dividend yield is considered by investors to guarantee large liquidity (ignoring the tax consequences). This is in line with the bird in hand theory in Gitman and Zutter (2012). Investors prefer to get dividends at this time compared to obtaining capital gains that are considered uncertain. Therefore, there is factor of uncertainty and fiduciary responsibilities which make large investors tend to choose to get dividends.

Based on Table 2, the results of the regression test with Eviews 8, obtained an Fstatistic value of 40.07992 with an F-statistic probability of 0.0000 . The results show a probability much smaller than 0.05 . Then, it can be concluded that the illiq coefficient, size, beta, risk and dividend yield are not equal to 0.0000 or the five independent variables simultaneously influencing the stock return. Therefore, the independent variables in this study can be used to estimate the dependent variable properly.

Based on Table 2, the results of the regression test with Eviews 8 show the amount of adjusted R2 of 0.611772 . Then, this means $61 \%$ change in the stock return variable can be explained by illiquidity, size, beta, risk and dividend yield variables. Meeanwhile, 39\% is explained by other variables not included in this research model. 


\section{Conclusion}

Based on the results of testing the hypothesis with the $t$ test in Eviews 8 the results is illiquidity and size do not significantly influence the stock return. This result is not in line with the hypothesis set at the beginning, namely variable illiquidity and size have a significant effect. This is because the illiquidity ratio has weakness if the zero volume is removed, it will increase the bias of the illiquidity ratio and also reduce the role of return to reduce the illiquidity ratio.

Related to size; the size of the company does not affect the company's stock return. This is because the size of the company does not consistently produce premium size. During the research period the premium size results can be negative or positive each year, so that when the pattern is measured year after year it is irregular. Even the size effect disappears due to the financial pressure that the company has due to default risk.

In relation to beta, risk and dividend yield variables from the test results, it gives a significant influence on the stock return. The higher the beta of a company's stock, the stock return has increased. This is because beta is used as a tool to measure risks that exist on the market (systematic risk) and the size of the return is influenced by the risks that are already on the market. Therefore beta is directly proportional to return.

The higher the risk of the company's stock, the stock return has decreased. This is because investors use the call option for hedging to avoid the marginal tax rate for capital gains and not experience loss. The magnitude of the call option value is directly proportional to residual risk but inversely proportional to return. Therefore risk is inversely proportional to return.

The higher the dividend yield, the stock return decreases. This is because large investors tend to prefer companies with high liquidity and large dividends to minimize the cost of equity and fulfill fiduciary responsibilities. The high dividend yield is considered by investors to guarantee large liquidity (ignoring the tax consequences). Therefore, dividend yield is inversely proportional to return.

Based on the results of the $\mathrm{F}$ test on Eviews 8, the value is 40.07992 with the probability of 0.0000 . From these results, it can be concluded that independent variables (illiquidity, size, beta, risk and dividend yield) simultaneously affect stock return. Based on the regression results, adjusted $\mathrm{R}^{2}$ sebesar 0.611772 is obtained. With these results, dependent variable (stock return) can be explained well by independent variables (illiquidity, size, beta, risk and dividend yield).

\section{References}

Amihud Y, Mendelson H. 1991. Liquidity, Aset Price and Financial Policy. Financial Analysts Journal. 47(6): 55-56.

Amihud Y, Mendelson H. 1986. Asset Pricing and Bid-Ask Spread. Journal of Financial Economics. 15: 223-249.

Amihud Y, Mendelson H. 1989. The Effects Beta, Bid-Ask Spread, Residual Risk and Size on Stock Returns. The Journal of Finance. 44(2): 479-486.

Amihud Y. 2002. Illiquidity And Stock Returns: Cross-Section And Time-Series Effect. Journal Of Financial Markets. 5: 31-56.

Amihud Y, Hameed A, Kang W, Zhang H. 2015. The Illiquidity Premium: International Evidence. Journal of Financial Economics. 117: 350-368.

Atkins AB, Dyl EA. 1997. Transactions Costs and Holding Periods for Common Stocks. Journal of Finance. 52: 309-325.

Berk J. 1995. A Critique of Size-Related Anomalities. Review of Financial Studies. 8: 275-286.

Black F, Jensen MC, Scholes M. 1972. The Capital Asset Pricing Model: Some Empirical Test. Studies in the Theory of Capital Markets. New York: Praeger. 
Brown P, Kleidon AW, Marsh TA. 1983. New Evidence on the Nature Size-Related Anomalities Stock Prices. Journal of Financial Economics. 12: 33-56.

Cao C, Petrasek L. 2014. Liquidity Risk In Stock Returns: An Event-Study Perspective. Journal Of Banking and Finance. 45: 72-83.

Chelley-Steeley PL, Lambertides N, Steeley JM. 2015. The Effects of Non-Trading on the Illiquidity Ratio. Journal of Empirical Finance. 34: 204-228.

Constantinides GM, Scholes MS. 1980. Optimal Liquidation of Assets in the Presence of Personal Taxes: Implication for Asset Pricing. Journal of Finance. 35: 439-443.

Copeland TC, Galai D. 1983. Information Effect on the Bid-Ask Spread. Journal of Finance. 38: 1457-1469.

Damodaran A. 2001. Corporate Finance: Theory and Practice $2^{\text {nd }}$ Edition. New York: Wiley International Edition.

Damodaran A. 2001. The Dark Side of Valuation: Valuing Old Tech, New Tech, and New Economy Companies. New Jersey: Prentice Hall Inc.

Francis JC. 1988. Management of Investment $2^{\text {nd }}$ Edition. Singapore: McGraw Hill Inc.

Ghozali I, Dwi R. 2013. Analisis Multivariat dan Ekonometrika Teori, Konsep dan Aplikasi dengan Eviews 8. Semarang: Badan Penerbit Universitas Diponegoro.

Ghozali I. 2005. Aplikasi Multivariate dengan Program SPSS. Semarang: Badan Penerbit Universitas Diponegoro.

Gitman LJ, Zutter CJ. 2012. Principles of Managerial Finance $13^{\text {th }}$ Edition. New Jersey: Prentice Hall.

Glosten LR, Milgrom PR. 1985. Bid, Ask and Transaction Prices in a Specialist Market with Heterogeneously Informed Traders. Journal of Financial Economics. 14: 71-100.

Gujarati DN. 2004. Basic Econometric. Edisi 4. New York: The McGraw-Hill.

Hartono J, Surianto. 2000. Bias in Beta values and its Correction. Gadjah Madda International Journal of Business. 2(3): 337-349.

Hodrick RJ. 1992. Dividend Yields And Expected Stock Returns: Alternative Procedures For Inference And Measurement. The Review Of Financial Studies. 5(3): 357-386.

Jones CP. 1996. Investment Analysis and Management $5^{\text {th }}$ Edition. New York: John Wiley \& Sons Inc.

Jones CP. 2002. Investment Analysis and Management $8^{\text {th }}$ Edition. New York: John Wiley \& Sons Inc.

Jones RG, Dudley D. 2000. Essential of Finance $2^{\text {nd }}$ Edition. New Jersey: Prentice Hall.

Lemmon ML, Nguyen T. 2015. Dividend Yields and Stock Return in Hong Kong. Journal of Managerial Finance. 41: 164-181.

Megginson WL, Smart SB, Graham J. 2010. Financial Management $3^{\text {rd }}$ Edition. South Western Publishing.

Murhadi WR, Irawan R. 2012. Analisis Pengaruh Three Factor Model dan Persentase Kepemilikan Asing Terhadap Tingkat Return di Bursa Efek Indonesia. Jurnal Manajemen dan Bisnis. 10(2): 213-226.

Murhadi WR. 2013. Pengaruh Idiosyncratic Risk dan Likuiditas Saham Terhadap Return Saham. Jurnal Manajemen \& Kewirausahaan UK Petra. 15: 33-40.

Murhadi WR. 2015. Analisis Laporan Keuangan Proyeksi dan Valuasi saham. Jakarta: Salemba Empat.

Pastor L, Stambaugh RF. 2003. Liquidity Risk and Expected Stock Returns. Journal of Political Economy. 111: 642-685.

Patel JB. 2012. A Further Analysis of Small Firm Stock Returns. Managerial Finance. 38(7): 653-659.

Redding LS. 1997. Firm Size and Dividen Payouts. Journal of Financial Intermediation. 6: 224-248.

Reilly FK. 1992. Investments $3^{\text {rd }}$ edition. Orlando: Harcourt Brace Jovanovich College 


\section{Publisher.}

Ross SA, Westerfield RW, Jordan BD. 2003. Fundamental of Corpotate Finance. Sixth Edition. New York: The McGraw-Hill..

Savin NE, White KJ. 1977. The Durbin-Watson Test for Serial Correlation with Extreme Sample Sizes or Many Regressors. Econometrica. 45: 1988-1996.

Sears RS, Trennepohl GL. 1993. Investment Management. Orlando:The Dryden Press Harcoun College Publishers.

Sulistio H. 2005. Pengaruh Informasi Akuntansi dan Non Akuntansi Terhadap Initial Return: Studi Pada Perusahaan yang Melakukan Go Public Offering di Bursa Efek. Simposium Nasional Akuntansi VIII Solo.

Tulasi D. 2006. Kemampuan Rasio Keuangan dan Ukuran Perusahaan dalam Memprediksi Kinerja Keuangan (Studi Perusahaan Tekstil dan Produk Tekstil yang tercatat di bursa Efek Jakarta). Jurnal widya Manajemen \& Akuntansi. 6(3): 366-384.

Weston JF, Brigham EF. 1993. Essential of Managerial Finance. Tenth Edition. Orlando:The Dryden Press.

Weston JF, Copeland TE. 1992. Managerial Finance $9^{\text {th }}$ Edition. USA: The Dryden Press.

Wyss RV. 2004. Measuring and Predicting Liquidity in The Stock Market. [Dissertation]. Swiss: der Universit ̈̈at St. Gallen. 